UDK [664.849:635.64]: 636.4.085.55 DOI: https://doi.org/

\section{ONAFT}

Open Access

O. Karunskyi ${ }^{1}$, Doctor of Agricultural Sciences, Professor https://orcid.org/ 0000-0001-8180-1587, Researcher ID: B-3788-2016

O. Voietska ${ }^{2}$, PhD Technical Sciences, Associate Professor, E-mail: vecombi@gmail.com https://orcid.org/ 0000-0002-2029-7484, Researcher ID: C-7090-2016,

Scopus Author ID: 57192818925

I. Cherneha ${ }^{2}$, PhD Technical Sciences, Associate Professor, E-mail: ilonamalaki@gmail.com https://orcid.org/0000-0002-9507-8489, Researcher ID: C-1457-2016

V. Fedoryaka, Doctor of Agricultural Sciences, Associate Professor ${ }^{1}$ Odessa State Agrarian University, 13, Panteleimonovska Str., Odessa, 65039, Ukraine, ${ }^{2}$ Odessa National Academy of Food Technologies, 112, Kanatna Str., Odessa, 65039, Ukraine Tel. +380487124113

\title{
EFFECTIVENESS OF THE USE OF TOMATO SHOOTS IN PIG BREEDING
}

\begin{abstract}
The further development of animal husbandry requires more active involvement of all factors that increase milk and meat production. The widespread use of recyclable canning production in the diets of farm animals is one of the important resources for strengthening and developing the feed base. Efforts aimed at the practical solution of the problem of the use of secondary raw materials of the food industry are rightly considered at the same level as the implementation of measures to increase the yield of fodder crops. In conditions of production, animals are not always provided with complete diets, especially for protein, vitamins and other biologically active substances. One method of balancing pigs' diets for nutrients and biologically active substances may be to feed them tomato shoots. Tomato squeezes can replace some of the forage that is included in the feed mix.

Tomato shoots have a wide range of biological activity, and therefore using them as a feed additive can normalize the metabolic processes of the animal body, improve the function of the digestive system. However, there are no clear guidelines for the inclusion of tomato shoots in pig feeds today. In addition, there is still no consensus among researchers on the relatively optimal way of harvesting, preserving and storing these unconventional feeds.

The purpose of the work was to justify the optimal levels of tomato shoots animals in the feed for young pigs for fattening. In the course of the research, the chemical composition and nutritional value of tomato shoots were analyzed, compound feed recipes were developed with partial replacement of grain components for tomato shoots, the effect of the developed compound feeds on feeding them on the growth of pigs and peculiarities of the influence of tomato buds were studied, their rational use in pig production is substantiated.

The results of the experiment indicate the feasibility of replacing in the feed for the repair of young pigs part of the raw material for tomato shoots. Studies have shown that feeding young pigs with tomato shoots leads to a slight decrease in the digestion of nutrients. Analysis of the daily average nitrogen balance indicates better deposition of it in the body of the animals of the experimental groups, which fed 10 and $15 \%$ of tomato shoots. At feeding of $20 \%$ of tomato shoots nitrogen balance worsened considerably.
\end{abstract}

Key words: tomato shoots, fodder, fattening pigs.

\section{Literary review}

The further development of animal husbandry requires more active involvement of all factors that increase milk and meat production. The widespread use of recyclable canning production in diets of farm animals is one of the important resources for strengthening and developing the feed base. Efforts aimed at the practical solution of the problem of the use of secondary raw materials of the food industry are rightly considered at the same level as the implementation of measures to increase the yield of fodder crops.

Feeding efficiency of canning secondary raw materials depends to a large extent on its composition, availability of biologically active substances, functional state of digestive organs and animal feeding system [1, 2].

Therefore, research on the use of secondary raw materials for canning production in pigs in order to increase their productivity is important scientific and economic value and is relevant.
In conditions of production, animals are not always provided with complete diets, especially for protein, vitamins and other biologically active substances. One way of balancing pigs' diets for nutrients and biologically active substances may be to feed them tomato shoots. Tomato shoots can replace some of the forage that is included in the feed mix.

According to a number of authors, the use of tomato shoots in feeding pigs leads to a more complete use of feed by increasing their digestibility and nutrient absorption.

Tomato shoots have a wide range of biological activity, and therefore using them as a feed additive can normalize the metabolic processes of the animal body, improve the function of the digestive system $[3,4]$.

A number of papers provide information on the successful use of tomato shoots as a rational substitute for grain feed in the diets of young pigs, but there are no clear recommendations for the inclusion of tomato bovine feed in pigs for today. In addition, there is still no 
consensus among researchers on the relatively optimal way of harvesting, preserving and storing these unconventional feeds $[5,6,7]$.

In this regard, the study of the effectiveness of the use of tomato shoots in pig diets is of great scientific and practical importance.

\section{Formulation of the problem}

The purpose of this work is to substantiate the optimal levels of tomato shoots pigs in feed for young pigs for fattening.

To achieve this goal it is necessary to perform the following tasks:

- determine the chemical composition and nutritional value of tomato shoots;

- to develop compound feed recipes with partial replacement of their cereal components by tomato shoots;

- to study the influence of the developed compound feeds on feeding them in the composition of the diet on the growth of pigs;

- to study the features of the influence of tomato shoots on pig growth and development;

- to justify their rational use in pig production.

\section{Materials and methods}

The studies were conducted in production conditions on pigs of large white breed. Four pig groups were formed using the analogue group at 4 months of age with 4 heads on which the experiments were conducted. Animals were selected homogeneous by sex and live weight. The diet of the animals was prepared according to the current norms, taking into account the age and live weight of the experimental animals. Based on the analyzes of the composition and nutrition of the diets, their balancing was performed according to 28 indicators. According to the scheme of the experiment, animals of each group received standard compound feed. In the diet of the experimental groups, instead of concentrated feed, tomato washes were administered in the following amount (by weight): group $2-10 \%$; 3rd group $-15 \%$; group $4-20 \%$. Sampling of the average samples of forages, faeces (feces, urine) and their zoochemical analysis was carried out according to conventional methods.

\section{Results of the study and their discussion}

In the first phase of the study, tomato shoots were analyzed for nutrient content. Table 1 presents the main indicators of the chemical composition of fresh and dried tomato shoots in comparison with barley grain.

In the presence of protein and fat, tomato shoots exceed the content of these nutrients in barley grain by several times. There are $34.1 \mathrm{~g}$ of calcium and $36.3 \mathrm{~g}$ of phosphorus in $1 \mathrm{~kg}$ of tomato shoots. Accordingly, calcium is 17 times higher than in barley grain, which is the basis of the diet for pigs. Summarizing the material presented, we can conclude that tomato shoots are characterized by a relatively high forage potential, characterized by a diverse composition of biologically active substances.

At present, rising prices for compound feed and significant transportation costs for transportation of raw materials and finished products have led to the need to
Table 1 - Chemical composition and nutritional value offeed

\begin{tabular}{|c|c|c|c|}
\hline \multicolumn{4}{|c|}{ Chemical composition, $\%$} \\
\hline \multirow{2}{*}{ Indicators } & \multicolumn{2}{|c|}{ Tomato shoots } & \multirow{2}{*}{$\begin{array}{c}\text { Barley } \\
\text { grain }\end{array}$} \\
\hline & moist & is dry & \\
\hline Moisture & 73,4 & 13,0 & 12,8 \\
\hline Crude protein & 6,7 & 22,6 & 11,2 \\
\hline Crude fat & 4,0 & 12,6 & 2,2 \\
\hline Crude fiber & 8,1 & 17,8 & 4,9 \\
\hline $\begin{array}{l}\text { Non-nitrogenous } \\
\text { extractives }\end{array}$ & 6,5 & 28,2 & 63,8 \\
\hline Cinder & 1,1 & 2,9 & 2,8 \\
\hline \multicolumn{4}{|c|}{ Energy and nutrient content in $1 \mathrm{~kg}$ of feed } \\
\hline \multirow{2}{*}{ Indicators } & \multicolumn{2}{|c|}{ Tomato shoots } & \multirow{2}{*}{$\begin{array}{c}\text { Barley } \\
\text { grain }\end{array}$} \\
\hline & moist & is dry & \\
\hline Feed units & 0,2 & 0,7 & 1,15 \\
\hline $\mathrm{Ca}, \Gamma$ & 3,1 & 34,1 & 2,0 \\
\hline $\mathrm{P}, \Gamma$ & 3,8 & 36,3 & 3,9 \\
\hline
\end{tabular}

Table 2 - Recipes and nutrition of feed for pigs, \%

\begin{tabular}{|c|c|c|c|c|}
\hline \multirow{2}{*}{$\begin{array}{c}\text { Components and } \\
\text { nutrients }\end{array}$} & \multicolumn{4}{|c|}{ Recipes } \\
\hline & 1 & 2 & 3 & 4 \\
\hline Maize & 40,0 & 40,0 & 40,0 & 40,0 \\
\hline Pea & 26,0 & 26,0 & 26,0 & 26,0 \\
\hline Barley & 20,0 & 10,0 & 5,0 & - \\
\hline Meat-bone meal & 7,5 & 7,5 & 7,5 & 7,5 \\
\hline Herbal meal & 5,0 & 5,0 & 5,0 & 5,0 \\
\hline Tomato shoots & - & 10,0 & 15,0 & 20,0 \\
\hline Salt & 0,5 & 0,5 & 0,5 & 0,5 \\
\hline Premix & 1,0 & 1,0 & 1,0 & 1,0 \\
\hline \multicolumn{5}{|c|}{$1 \mathrm{~kg}$ of compound feed contains: } \\
\hline Feed units & 1,15 & 1,08 & 1,05 & 1,03 \\
\hline Exchange energy, MJ & 12,70 & 12,08 & 11,79 & 11,46 \\
\hline Dry matter, $\mathrm{g}$ & 838 & 840 & 841 & 842 \\
\hline Crude protein, $\mathrm{g}$ & 155,5 & 154,5 & 154,1 & 153,5 \\
\hline Digestible protein, $\mathrm{g}$ & 125,1 & 118,6 & 115,3 & 112,0 \\
\hline Crude fiber, $\mathrm{g}$ & 51,9 & 69,8 & 78,7 & 87,7 \\
\hline Lysine, $\mathrm{g}$ & 7,4 & 7,1 & 7,0 & 6,8 \\
\hline Methionine+cystine, $\mathrm{g}$ & 4,3 & 4,2 & 4,2 & 4,1 \\
\hline Salts, $\mathrm{g}$ & 5,0 & 5,0 & 5,0 & 5,0 \\
\hline Calcium, $\mathrm{g}$ & 11,7 & 12,5 & 12,9 & 13,3 \\
\hline Phosphorus, g & 9,5 & 9,0 & 8,9 & 8,9 \\
\hline Iron, $\mathrm{g}$ & 164,6 & 259,6 & 307,5 & 355,1 \\
\hline Midi, mg & 11,5 & 10,8 & 10,5 & 10,3 \\
\hline Zinc, mg & 54,7 & 51,4 & 51,5 & 57,1 \\
\hline Manganese, mg & 44,2 & 41,5 & 40,4 & 39,6 \\
\hline Cobalt, mg & 1,15 & 1,10 & 1,06 & 1,04 \\
\hline Iodine, $\mathrm{mg}$ & 0,2 & 0,2 & 0,2 & 0,2 \\
\hline Carotene, mg & 9,2 & 9,5 & 9,7 & 9,9 \\
\hline Vitamins: & 0,336 & 0,316 & 0,307 & 0,301 \\
\hline $\mathrm{D}$, thousand IU & 38,5 & 36,2 & 35,2 & 34,5 \\
\hline $\mathrm{E}, \mathrm{mg}$ & 4,4 & 4,1 & 4,0 & 3,8 \\
\hline $\mathrm{B}_{1}, \mathrm{mg}$ & 6,7 & 6,3 & 6,1 & 6,0 \\
\hline $\mathrm{B}_{2}, \mathrm{mg}$ & 21,7 & 20,4 & 19,8 & 19,5 \\
\hline $\mathrm{B}_{3}, \mathrm{mg}$ & 1,11 & 1,04 & 1,01 & 0,99 \\
\hline $\mathrm{B}_{4}, \mathrm{~g}$ & 66,1 & 62,2 & 60,6 & 59,3 \\
\hline $\mathrm{B}_{5}, \mathrm{mg}$ & 5,3 & 5,0 & 4,9 & 4,8 \\
\hline $\mathrm{B}_{12}, \mathrm{mcg}$ & & & & \\
\hline
\end{tabular}


Table 3 - Nutrient digestibility of rations in experimental pigs, \%

\begin{tabular}{|c|c|c|c|c|}
\hline \multirow{3}{*}{ Nutrients } & \multicolumn{4}{|c|}{ Group } \\
\hline & \multicolumn{2}{|c|}{ Control } & \multicolumn{2}{|c|}{ Experienced } \\
\hline & 1 & 2 & 3 & 4 \\
\hline Dry matter & $80,9 \pm 0,93$ & $74,7 \pm 1,48$ & $77,2 \pm 1,92$ & $\overline{72,8 \pm 0,81}$ \\
\hline Organic matter & $85,5 \pm 2,09$ & $84,4 \pm 1,26$ & $83,0 \pm 2,41$ & $79,6 \pm 1,09$ \\
\hline Crude protein & $79,0 \pm 1,53$ & $78,1 \pm 1,64$ & $77,9 \pm 2,25$ & $76,8 \pm 2,61$ \\
\hline Crude fat & $63,7 \pm 2,83$ & $60,9 \pm 3,40$ & $57,3 \pm 3,11$ & $52,2 \pm 4,84$ \\
\hline Crude fiber & $46,1 \pm 4,58$ & $45,8 \pm 2,76$ & $39,4 \pm 4,27$ & $39,6 \pm 3,33$ \\
\hline Non-nitrogenous extractives & $93,7 \pm 3,16$ & $93,4 \pm 0,95$ & $93,0 \pm 1,20$ & $93,2 \pm 1,75$ \\
\hline
\end{tabular}

Table 4 - Average daily nitrogen balance in the animals of the experimental groups

\begin{tabular}{|c|c|c|c|c|}
\hline \multirow{3}{*}{ Indicators } & \multicolumn{4}{|c|}{ Group } \\
\hline & \multicolumn{2}{|c|}{ Control } & \multicolumn{2}{|c|}{ Experienced } \\
\hline & 1 & 2 & 3 & 4 \\
\hline Obtained with feed, $g$ & $45,23 \pm 0,91$ & $49,95 \pm 1,36$ & $52,51 \pm 0,49$ & $54,76 \pm 1,11$ \\
\hline Highlighted with feces, $g$ & $9,49 \pm 0,45$ & $10,92 \pm 0,84$ & $11,59 \pm 1,14$ & $12,71 \pm 0,54$ \\
\hline Digested, $\mathrm{g}$ & $35,74 \pm 0,53$ & $39,05 \pm 0,95$ & $40,92 \pm 0,82$ & $42,05 \pm 1,08$ \\
\hline Isolated with urine, $g$ & $15,55 \pm 1,40$ & $16,49 \pm 1,89$ & $16,51 \pm 0,48$ & $20,78 \pm 1,64$ \\
\hline Snoozed in the body, $g$ & $20,19 \pm 0,56$ & $22,54 \pm 0,71$ & $24,41 \pm 0,50$ & $21,27 \pm 1,36$ \\
\hline \multicolumn{5}{|l|}{ Snoozed (\%) from: } \\
\hline accepted & 44,6 & 45,1 & 46,5 & 38,8 \\
\hline digested & 56,5 & 57,7 & 59,6 & 50,6 \\
\hline
\end{tabular}

produce compound feed directly in farms. Approximation of compound feed production to the place of consumption raised the question of developing district compound feed recipes. Recipes of compound feeds for pigs in farms are made taking into account the zonal characteristics of feeding and the conditions of agricultural production.

For the sake of cheaper diets for pigs' repair young animals, compound feed recipes have been developed which provide for the partial replacement of expensive grain feeds with an equivalent amount of tomato meal flour. Combined feed recipes were developed based on the nutrient content of the main feeds (Table 2).

The fiber content in the diets of the study groups increased in proportion to the amount of tomato waste input. Given the changes in the amount of fiber in the diets of animals, it was important to determine the effect of this factor on the digestibility of basic nutrients (Table 3).

Analysis of the data in Table. 3, shows that the nutrient digestibility of the diets was quite high.

So, the solubility of dry matter was $80.9 \ldots 72.8 \%$, organic matter $-85.5 \ldots 79.6 \%$, protein $79.0 \ldots 76.8 \%$, fat $-63.7 \ldots 52.2 \%$, fiber $-46.1 \ldots 39.4 \%$, non-nitrogenous extractives $-93.7 \ldots 93.0 \%$. It should be noted that the digestibility of nutrients by animals fed by tomato shoots decreased depending on their number.

Thus, in contrast to the 1 st control group, the solubility of the dry matter of the 2 nd experimental group was $74.7 \%$, 3rd $-77.2 \%$, 4th $-72.8 \%$. The difference in favor of the control group was $6.2 ; 3.7$ and 8.1 absolute percentages. The digestibility of organic matter in the study groups was also inferior to the control, by 1.1 ; 2.5 and $5.9 \%$, in which this indicator was $85.5 \%$.

Analysis of the digestibility of the crude protein showed that the animals of the control group digested it by $79.0 \%$. In pigs of the 2 nd and 3rd experimental groups this indicator decreased slightly - to the level of 78.1 and $77.9 \%$ respectively. The lowest protein digestibility ratio of $76.8 \%$ was found in young animals of the 4th experimental group, fed by $20 \%$ of tomato extracts (by weight) of the diet.

It was proved that the fat digestibility ratio of pigs treated with tomato extracts was $60.9 ; 57.3$ and 52.2 $\%$. In pigs from the control group, the fat digestibility was higher and was $63.7 \%$.

With regard to the digestibility of fiber, it is easy to see that with increasing its amount in the diet, this figure decreases from $46.1 \%$ in the control group to $45.8 \%$ in the 2 nd; $39.4 \%$ - in the $3 \mathrm{rd} ; 39.6 \%$ - in the 4 study groups.

The increase in tomato feces in pigs' diets did not affect the digestibility of nitrogen-free extracts by the organism of young animals of $1-4$ groups $(93.0 \ldots 93.7 \%)$. However, despite some reduction in the digestibility of nutrients in the animals of the experimental groups, the level of their absorption was quite high. 
In the study of metabolism, in particular proteins, the degree of nitrogen deposition in the body of animals is of particular importance, since this indicator most accurately determines the intensity of the synthesis of organic substances, as well as the increase in live weight of pigs for fattening by increasing meat. Therefore, along with nutrient digestibility, an important step in our research was the study of nitrogen metabolism (Table 4).

The use of tomato shoots in the diets of pigs provided a positive balance of nitrogen in all experimental young. In pigs of the 2 nd and 3rd experimental groups the deposition of nitrogen in the body increased by 0.5 and $1.9 \%$, respectively, amounting to 45.1 and $46.5 \%$ of the accepted one, in each group it was an average of $44.6 \%$. Feeding $20 \%$ of tomato shoots in the diet led to a decrease in nitrogen deposition in the young of the fourth experimental group by 5.8 absolute percent, compared with the control group.

The main indicator of the nitrogen exchange rate is its balance. In pigs of the 2nd and 3rd experimental groups, the average nitrogen content was 22.54 and 24.41 per day, respectively, or $2.35 \mathrm{~g}(\mathrm{p}>0.95)$ and $4.22 \mathrm{~g}(\mathrm{p}>$ 0.999 ) more than the control animals, where it was 20.19 g. In the young of the 4th experimental group, which received $20 \%$ of tomato shoots in the diet, the lowest amount of nitrogen was $21.27 \mathrm{~g}$ compared with other experimental groups, but by $1.08 \mathrm{~g}$ more than in the control group.

\section{Conclusion}

The results of the experiment indicate the feasibility of replacing in the feed for the repair of young pigs part of the raw material of tomatoes. As a result of the research found that feeding young pigs tomato shoots leads to a slight decrease in the digestion of nutrients. Analysis of the daily average nitrogen balance indicates better deposition of it in the body of the animals of the experimental groups, which fed 10 and $15 \%$ of tomato shoots. When fed with $20 \%$ tomato shoots nitrogen balance significantly deteriorated.

\title{
REFERENCES
}

1. Korobko V. N. Otkhody plodoovoshchnoho proizvodstva - rezerv ukrepleniya kormovoy bazy zhivotnovodstva. Khranenie i pererabotka zerna. 2002; 26 (1): 53-55.

2. Ispolzovanie otkhodov proizvodstva konservov: [Veb-sayt]. 2014. URL: https://msd.com.ua/texnologiya-pishhevyxproizvodstv/ispolzovanie-otxodov-proizvodstva-konservov/(data zvernennya: 04.02.2020).

3. Ehorov B. V., Malaki I. S. Perspektivy ispol zovaniya pobochnykh produktov konservnykh proizvodstv. Zernovi produkti i kombikormi. 2013; 52 (4): 28-32.

4. Ehorov B. V., Malaki I. S., Sharova A. I. Ispol zovanie otkhodov pererabotki tomatov v sostave kombikormov. Khranenie i pererabotka zerna. 2014; 185 (8): 44-46.

5. Ehorov B. V., Voetskaya E. E., Malaki I. S. Fizicheskie svoystva i sanitarnoe kachestvo tomatnykh vyzhimok. Zernovi produkti i kombikormi. 2014; 53 (1): 42-44.

6. Ibatulin I. I. Hodivlya silskohospodarskikh tvarin. Vinnitsya: Nova kniha; 2007.

7. Karunskyi O. Y., Riznichuk I. F., Dashkovska O. P. Naukove obtruntuvannya hodivli sviney. Odesa; 2004.

УДК [664.849:635.64]: 636.4.085.55

О. Й. Карунський ${ }^{1}$, д-р с.-г. наук, професор https://orcid.org/ 0000-0001-8180-1587, Researcher ID: B-3788-2016

О. С. Воєцька ${ }^{2}$, канд. техн. наук, доцент, E-mail: vecombi@gmail.com https://orcid.org/ 0000-0002-2029-7484, Researcher ID: C-7090-2016,

Scopus Author ID: 57192818925

I. С. Чернега ${ }^{2}$, канд. техн. наук, доцент, E-mail: ilonamalaki@gmail.com https://orcid.org/0000-0002-9507-8489, Researcher ID: C-1457-2016

В.П. Федоряка, д-р с.-г. н., доцент

${ }^{1}$ Одеський державний аграрний університет, вул. Пантелеймонівська, 13, м. Одеса, 65039, Украӥна

${ }^{2}$ Одеська начіональна академія харчових технологій, вул. Канатна, 112, Одеса, 65039, Украйна Tel. +380487124113

\section{ЕФЕКТИВНІСТЬ ВИКОРИСТАННЯ ТОМАТНИХ ВИЧАВКІВ У ВІДГОДІВЛІ СВИНЕЙ}

\begin{abstract}
Анотація
Подальший розвиток тваринництва вимагає більи активного включення всіх чинників, які збільшують виробництво молока і м'яса. Широке використання вторинної сировини консервного виробництва в раціонах сільськогосподарських тварин - ие один із важливих ресурсів зміцнення і розвитку кормової бази. Зусилля, направленні на практичне вирішення проблеми використання вторинної сировини харчової промисловості правомірно розглядати на тому ж рівні, як виконання мір по підвищенню врожаю кормових культур. В умовах виробництва не завжди тварини забезпечені повноцінними раціонами, особливо по білку, вітамінам і іншими біологічно активними речовинами. Одним із методів балансування раціонів свиней за поживними та біологічно ак-
\end{abstract}


тивними речовинами може бути згодовування їм томатних вичавків. Томатні вичавки можуть заміняти частину зернових кормів, які входять до структури повнорачіонних комбікормів.

Томатні вичавки володіють широким спектром біологічної активності, а тому використання їх у якості кормової добавки дозволяе нормалізувати обмінні прочеси організму тварин, покращити функиії травної системи. Але чітких рекомендачій щодо норм включення томатних вичавків у склад комбікормів для свиней на сьогодні немає. Крім того, серед дослідників поки що немає єдиної думки і відносно оптимального способу заготівлі, консервування та зберігання циих нетрадииійних кормів.

Мета роботи полягала в обтрунтуванні оптимальних рівнів томатних вичавків у складі комбікормів для молодняку свиней на відгодівлі. Під час досліджень проведено аналіз хімічного складу і поживної иінності томатних вичавків, розроблено рецепти комбікормів з частковою заміною у них зернових компонентів на томатні вичавки, вивчено вплив розроблених комбікормів при згодовуванні їх у складі раціону на ріст свиней та особливості впливу томатних вичавків на ріст і розвиток свиней, обгрунтовано рачіональне їх використання у свинарстві.

Результати досліду свідчать про доиільність заміни у комбікормі для ремонтного молодняку свиней частини зернової сировини на томатні вичавки. У результаті проведених досліджень виявлено, щзо згодовування молодняку свиней томатних вичавків призводить до незначного зниження перетравлення поживних речовин. Аналіз середньодобового балансу азоту свідчить про краще відкладання його у тілі тварин дослідних груп, де згодовували 10 і $15 \%$ томатних вичавків. При згодовуванні 20 \% томатних вичавків баланс азоту помітно погіршувався.

Ключові слова: томатні вичавки, комбікорми, відгодівля свиней.

\section{ЛІТЕРАТУРА}

1. Коробко В.Н. Отходы плодоовощного производства - резерв укрепления кормовой базы животноводства. Хранение и переработка зерна. 2002. № 1. С. 53-55.

2. Использование отходов производства консервов: веб-сайт. URL: <http: //msd.com.ua/texnologiyapishhevyx-proizvodstv/ispolzovanie-otxodov-proizvodstva-konservov/(дата звернення: 04.02.2020).

3. Егоров Б.В., Малаки И.С. Перспективы использования побочных продуктов консервных производств. Зернові продукти і комбікорми. 2013. № 4 (52). С. 28-32.

4. Егоров Б.В., Шарова А.И., Малаки И.С. Использование отходов переработки томатов в составе комбикормов. Хранение и переработка зерна. 2014. № 8 (185). С. 44-46.

5. Егоров Б.В., Воечкая Е.Е., Малаки И.С. Физические свойства и санитарное качество томатных выжимок. Зернові продукти і комбікорми. 2014. № 1. С. 42-44.

6. Ібатулін I.I. Годівля сільськогосподарських тварин. Вінниия: Нова книга, 2007. 612 с.

7. Карунський О.Й., Різничук І.Ф., Дашковська О.П. Наукове обтрунтування годівлі свиней. Одеса, 2004. 140 c.

Received 12.10.2019
Reviewed 05.11.2019

Cite as Vancouver Citation Style

Karunskiy O., Voietska O., Cherneha I., Fedoryaka V. Effectiveness of the use of tomato shoots in pig breeding. Grain Products and Mixed Fodder's, 2020; 20 (1, 77): 36-40. DOI:

Cite as State Standard of Ukraine 8302:2015

Effectiveness of the use of tomato shoots in pig breeding / Karunskiy O. et al. // Grain Products and Mixed Fodder's. 2020. Vol. 20, Issue 1 (77). P. 36-40. DOI:

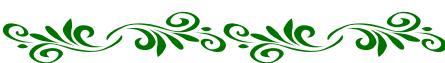

